\title{
Deformation analysis of concrete faced Aydın Karacasu dam and comparison of theoretical results with measurements
}

\author{
T.T. Tosun*, M.Y. Özkan, G.S. Yıldız and E. Çokça \\ Middle East Technical University, Department of Civil Engineering, Ankara, Turkey
}

\begin{abstract}
The improvement in design technologies has enhanced the use of different fill materials in construction of the embankment dams. Rockfill is one of the most preferred fill materials for embankment dam. Also, use of different fill material such as sand-gravel has been preferred in recent years. Previous studies on concrete faced sand-gravel fill dam (CFSGD), results of the laboratory experiments and in-situ testing analysis display that using sand-gravel as a fill material is not only cost-effective but also safe and provides high quality natural construction material. In this study, settlement of Karacasu Dam, which is the first concrete faced sand-gravel fill dam in Turkey, is examined for "end of construction" and "reservoir impoundment" loading conditions. Deformations are determined by computing two-dimensional finite element analyses. Hardening soil model is utilized to obtain non-linear, stress dependent and inelastic behavior of the sand-gravel fill material. Deformations which are calculated by finite element analyses, are compared with the data observed by General Directorate of State Hydraulic Works (DSI) for both end of the construction and reservoir impoundment periods. The comparison of the results indicates that calculated deformations are generally compatible with the observed ones.
\end{abstract}

\section{Keywords}

CFSGD; Deformation, 2D FEM; Hardening soil model; Sand-gravel fill

Received: 19 December 2018; Accepted: 03 January 2019

ISSN: 2630-5763 (online) (C) 2018 Golden Light Publishing ${ }^{\circledR}$ All rights reserved.

\section{Introduction}

With technological development and increased perfection in dam engineering, concrete face sandgravel dams (CFSGD) are widely used in today's world. Due to economic aspects, the application of sand-gravel fill materials, mostly alluvial deposits, is gaining more and more relevance as fill material. Safety of CFSGDs is based on construction, appropriate design, and observation of actual behavior during construction and operation of the structure. The most important problems encountered at CFSGDs is cracking of impervious face due to deformation behavior of dam body causing leakage [1].

The main objective of this study is to determine the deformation behavior of the Karacasu Dam, the first concrete faced sand-gravel dam in Turkey. In this study, deformations are calculated for both construction and water impoundment periods with the computer program PLAXIS [2]. The results taken from finite element analysis and observed data, obtained from General Directorate of State Hydraulic Works [3], are compared. Hardening soil model is used to represent sand-gravel material behavior in PLAXIS [2] during analyses since

\footnotetext{
Corresponding author

E-mail: tugce.tosun@kgm.gov.tr
} 
hardening soil model is a nonlinear and inelastic model.

\section{Concrete faced Aydın Karacasu dam}

Karacasu Dam was designed as a concrete faced sand-gravel fill dam (CFSGD) and construction of the Karacasu Dam was completed in 2012 [3]. Catchment area of the dam is $537 \mathrm{~km}^{2}$. Reservoir area is $1.07 \mathrm{~km}^{2}$ with $17.20 \mathrm{hm}^{3}$ total reservoir capacity and active storage volume of the dam is $13.70 \mathrm{hm}^{3}$. Total fill volume used in the design is $2,320,000 \mathrm{~m}^{3}$. A view of the general layout of Karacasu Dam is shown in Fig. 1.

Crest level of the dam is $298.50 \mathrm{~m}$ and crest length are $649.4 \mathrm{~m}$. Height of the dam is $60 \mathrm{~m}$ from foundation and $53.5 \mathrm{~m}$ from the river bed. Normal water level of the dam is $293.50 \mathrm{~m}$. Spillway of Karacasu Dam is uncontrolled. Discharge capacity of the spillway is $1389 \mathrm{~m}^{3} / \mathrm{s}$. A view of the

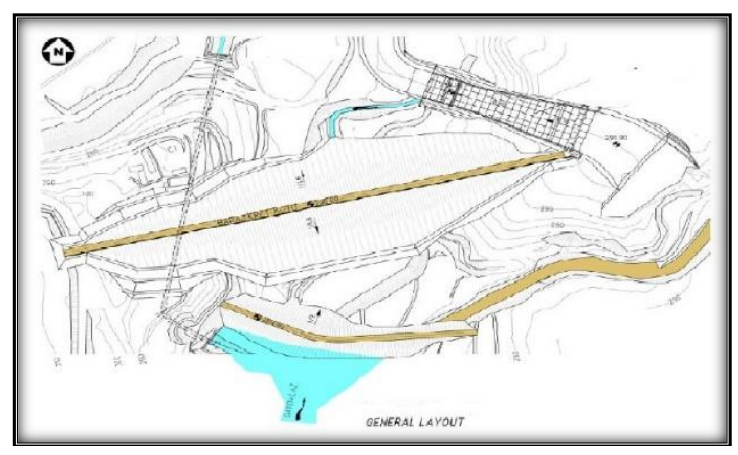

Fig. 1. A general layout of Karacasu Dam [3] maximum cross section and material zoning of Karacasu Dam are given in the Fig. 2.

In Fig. 2, "Zone 1A" represents the cohesionless fill; "Zone1B" shows the random fill, perimetric joint filter zone is shown by the symbol; " $2 \mathrm{~A}$ " and "Zone2B" represents the cushion zone under concrete slab; "Zone3A" shows the filter zone; "Zone3B" displays the permeable sand-gravel fill; "Zone3D" shows the drainage zone or filter zone (clear gravel) and " $\mathrm{K}$ " represents surface protection material. As can be seen in the Fig.2 above, the main construction material of Karacasu is sandgravel (Zone 3B).

Karacasu Dam is a moderate-sized dam. After the completion of main dam body, construction of concrete slab started. Concrete slab provides the impermeability and helps to decrease the leakage. Thickness of the concrete slab of Karacasu Dam is $30 \mathrm{~cm}$ and constant throughout the dam body.

According to results of petrographic analysis, the basic geologic formations at the Karacasu Dam site are denominated as marl, calcareous marl, limestone, clayey-sandy lignite, clayey lignite. Among these geologic formations, limestone has spongy configuration due to dissolution of rock and it is formed from microcrystalline, little clay and feldspar fragments. Few amounts of Clayey-sandy lignite, quartz, feldspar fragments, calcium carbonate and gypsum are seen in the sample. Base rock of the Aydin Karacasu Dam comprises of old neogene sediments (Foundation Boreholes of Aydın Karacasu Dam [3])

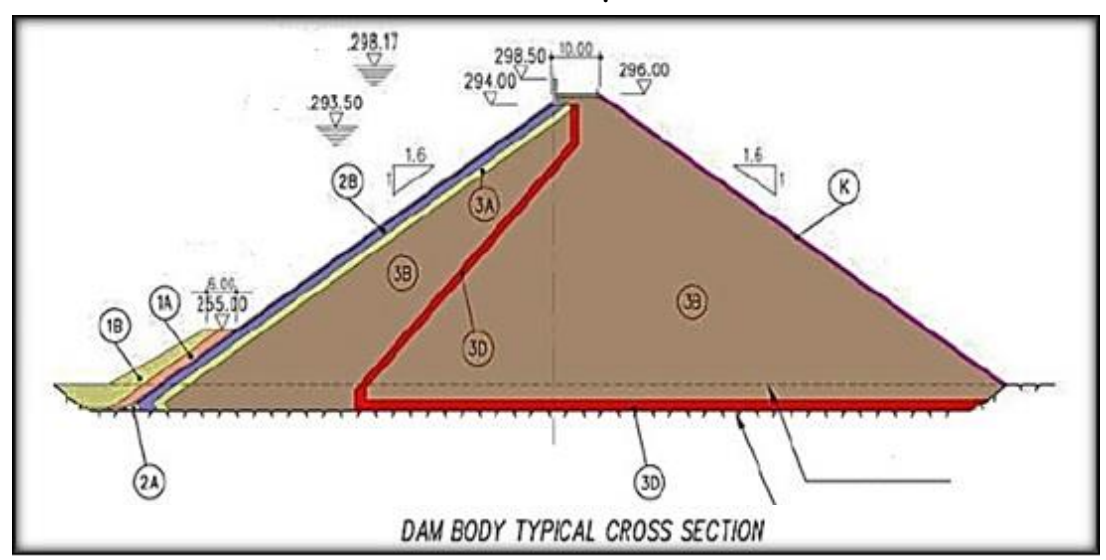

Fig. 2. The cross-section of Karacasu Dam [3] 


\subsection{Instrumentation of Aydin Karacasu dam}

The main purposes of dam instrumentation are to develop a better understanding of its behavior and to control the design concepts [4]. An instrumentation system is designed at Aydın Karacasu Dam.

30 hydraulic settlement gauge (ZDÖ) were installed in the Karacasu Dam body. Instruments were located at three different cross-sections $\mathrm{Km}$ $0+250.00 \mathrm{~m}, \mathrm{Km} 0+300.00 \mathrm{~m}, \mathrm{Km} 0+350.00 \mathrm{~m}$, respectively. The maximum cross-section of the dam body is the section located at $\mathrm{Km} 0+300.00 \mathrm{~m}$. Thus, instruments of $\mathrm{Km} 0+300.00 \mathrm{~m}$ are examined in this study.

\subsection{Observed settlement behavior of Aydin Karacasu dam}

According to the general schedule of the Aydin Karacasu Project, dam construction has started in December 2009 and the main body has filled to El. 296 m in February 2012 (20.02.2012). Reservoir impounding has officially started in September 2012; however, it is said that the reservoir has begun to rise two months after official impounding date. During these periods, the performance of the dam has been observed by instrumentation devices located at different elevations and cross-sections.
The settlements, which occur in the foundation and occur in the dam body, have been recorded respectively by hydraulic settlement devices. Hydraulic settlement devices are installed in three different cross-sections of the dam body ( $\mathrm{Km}$ 0+250.00m, Km 0+300.00m, Km 0+350.00m). Settlement devices are represented with a symbol of "ZDÖ" in this study. Location of these devices can be seen from Fig. 3 .

The maximum cross-section of the dam body is $\mathrm{Km} 0+300.00 \mathrm{~m}$. Maximum settlements occur at the maximum cross-section of the dam body, as expected [5]. According to the data taken from DSI, recorded values of hydraulic settlement devices located at $\mathrm{Km} 0+300.00 \mathrm{~m}$ are larger than the settlement values recorded on other cross-sections as expected. Hence, in this study, instrumentation devices installed in $\mathrm{Km} 0+300.00 \mathrm{~m}$ are taken into account. Fig. 3 shows the location of the hydraulic settlement device installed in $\mathrm{Km} 0+300.00 \mathrm{~m}$. They are installed at four different elevation El 245, El 260, El 275, El 290 at Km 0+300.00m.

Deformation behavior of the dam is studied for end of construction (EOC) and reservoir impoundment (RI) conditions. Observed settlement values, provided by DSI [3], are displayed in the Table 1.

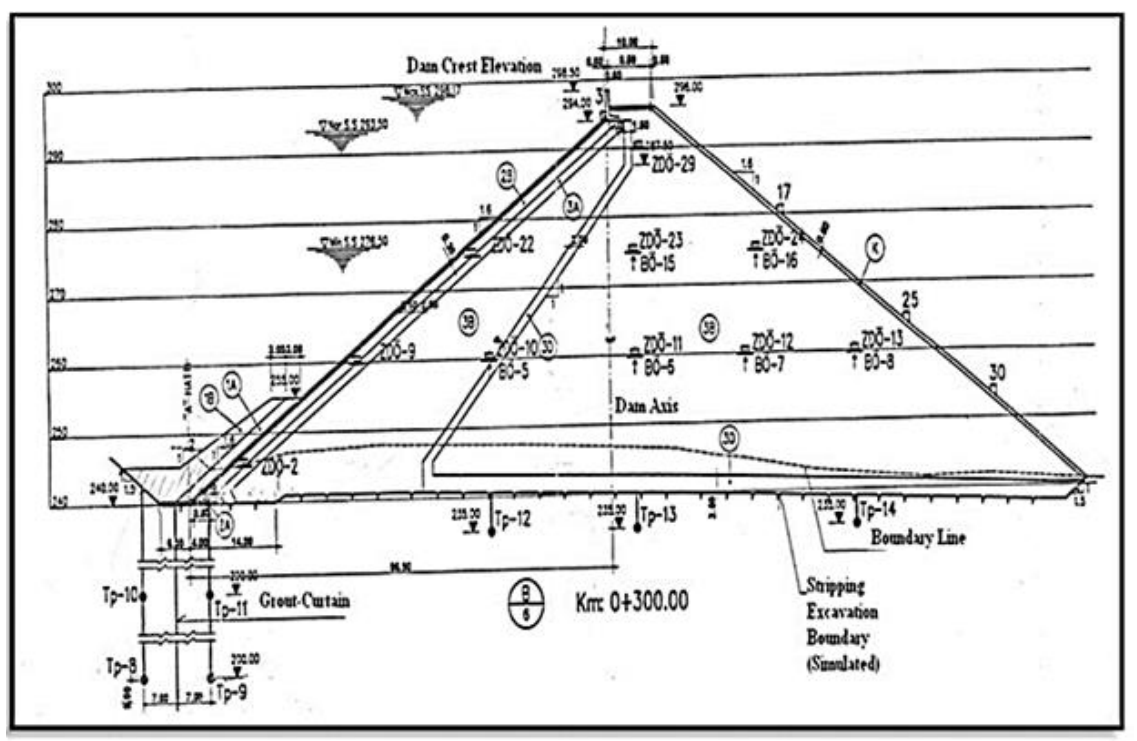

Fig. 3. Location of the hydraulic settlement devices of Aydın Karacasu dam at Km 0+300.00m [3] 
Table 1. Observed settlements for end of construction condition of Aydın Karacasu dam [3]

\begin{tabular}{ccccc}
\hline \multicolumn{5}{c}{ Observed vertical settlements at max. cross section of Karacasu dam $(\mathrm{Km} 0+300.00 \mathrm{~m})$} \\
\hline $\begin{array}{c}\text { Hydraulic } \\
\text { Settlement } \\
\text { Gauge }\end{array}$ & $\begin{array}{c}\text { Elevation } \\
(\mathrm{m})\end{array}$ & $\begin{array}{c}\text { Horizontal Distance } \\
\text { from Upstream Toe } \\
(\mathrm{m})\end{array}$ & $\begin{array}{c}\text { Max. Settlement Observed by } \\
\text { General Directorate of State } \\
\text { Hydraulic Works EOC }(\mathrm{cm})\end{array}$ & $\begin{array}{c}\text { Max. Settlement Observed by } \\
\text { General Directorate of State } \\
\text { Hydraulic Works RI }(\mathrm{cm})\end{array}$ \\
\hline ZDÖ2 & 245.00 & 19.50 & -32.00 & -42.00 \\
ZDÖ9 & 260.00 & 43.00 & -36.00 & -44.00 \\
ZDÖ10 & 260.00 & 70.00 & -22.00 & -32.00 \\
ZDÖ11 & 260.00 & 100.00 & -23.00 & -27.50 \\
ZDÖ12 & 260.00 & 132.50 & -27.00 & -40.00 \\
ZDÖ13 & 260.00 & 155.00 & -28.00 & -41.00 \\
ZDÖ22 & 275.00 & 67.00 & -28.00 & -41.00 \\
ZDÖ23 & 275.00 & 100.00 & -37.50 & -45.50 \\
ZDÖ24 & 275.00 & 135.00 & -32.00 & -42.00 \\
ZDÖ29 & 290.00 & 102.00 & -32.00 & -44.00 \\
\hline
\end{tabular}

\section{Analysis of Aydın Karacasu dam}

\subsection{Material model}

A constitutive law reflects the stress-strain relationship of materials. The key point in the analysis is modelling of the stress-strain relationships of sand gravel -fill materials, preferably based on triaxial test results. Among the material models used in the available studies carried out in recent years, Duncan and Chang's [6] hyperbolic model is probably the most common. In the present study, the "hardening soil model", which is essentially a modified implementation of the hyperbolic model available in PLAXIS [2] is used to represent the sand gravel -fill behavior (the deformation and settlement analysis of Aydin Karacasu Dam).

\subsection{Duncan and Chang's hyperbolic model}

Janbu [7] recommended a stress- dependent hyperbolic model, and Kondner [8] has shown that the nonlinear stress- strain behavior of soils can be approximated reasonably by hyperbolic stressstrain model. Since the model is simple and multidirectional, this model has been commonly in use for modeling behavior of soils. Kondner [8] expressed the soil stress-strain response with hyperbolic relation by Eq. (1),

$\frac{\varepsilon}{\sigma_{1}-\sigma_{3}}=\left[\frac{1}{E_{i}}+\frac{\varepsilon}{\left(\sigma_{1}-\sigma_{3}\right)_{u}}\right]$
Where $E_{\mathrm{i}}$ is the initial tangent modulus or initial slope of the stress-strain curve, and $(\sigma 1-\sigma 3)_{\mathrm{u}}$ is the asymptotic value of stress difference which is related to the strength of the soil; $\sigma_{1}$ and $\sigma_{3}$ are major and minor principal stresses; and $\varepsilon$ is axial strain. The ultimate stress difference is proportional to the compressive strength, or stress difference at failure $\left(\sigma_{1}-\sigma_{3}\right)_{\mathrm{f}}$, by the failure ratio, $R_{\mathrm{f}}$ which is defined by

$R_{f}=\frac{\left(\sigma_{1}-\sigma_{3}\right)_{f}}{\left(\sigma_{1}-\sigma_{3}\right)_{u}}$

The variation of $\left(\sigma_{1}-\sigma_{3}\right)_{\mathrm{f}}$ can be expressed in terms of the Mohr Coulomb criterion as in Eq. (3),

$\left(\sigma_{1}-\sigma_{3}\right)_{f}=\left[\frac{2 c \cos \phi}{1-\sin \phi}+\frac{2 \sin \phi}{1-\sin \phi} \sigma_{3}\right]$

Duncan and Chang [6] and Duncan [9] later published that for most types of soils, the value of $\mathrm{R}_{\mathrm{f}}$ can be taken as 0.9 .

Fig. 4 shows the relation between stress and strain [9]. Hyperbolic equation is transformed as shown in Fig. 4, it represents a linear relationship between $\left[\varepsilon /\left(\sigma_{1}-\sigma_{3}\right)\right]$ and $\varepsilon$.

Soil hardening model is similar to the Duncan and Chang's hyperbolic model (Fig. 5). Hardening soil model depends more on hardening plasticity than non-linear elasticity. Constraints and instability problems of Duncan-Chang's [6] hyperbolic model in terms of neutral loading and dilatancy are achieved. In addition to these features, the model also comprises of yield cap and dilatancy [10]. 


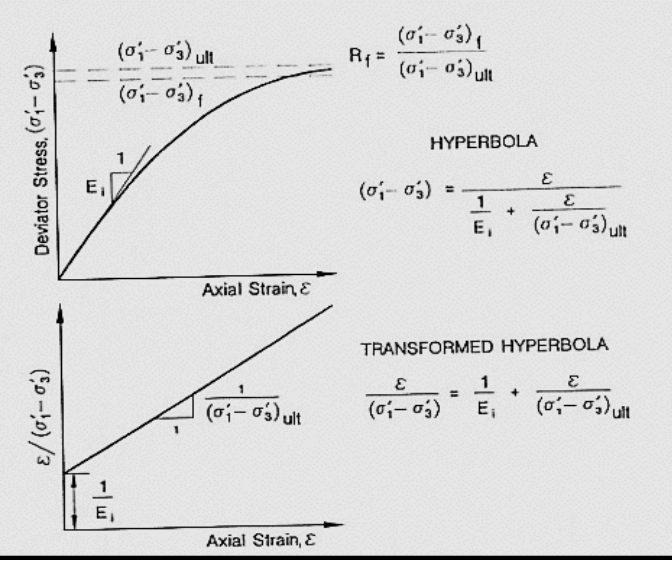

Fig. 4. Hyperbolic representation of a stress-strain relationship [9]

Some features of hardening model are stiffness that is based on stress respect to $m$, plastic straining as a result of $E^{\text {ref }} 50$ and $E^{\text {ref }}{ }_{\text {oed }}, E^{\text {ref }}{ }_{u r}, v_{u r}$ and failure criterion with respect to $c, \phi, \psi$ parameters of Mohr-Coulomb model, where,

$$
\begin{aligned}
& \mathrm{m} \quad \text { : power law } \\
& \mathrm{E}^{\mathrm{ref}}{ }_{50}: \text { primary deviator loading, } \\
& \mathrm{E}^{\mathrm{ref}}{ }_{\text {oed }} \text { : primary compression, } \\
& \mathrm{E}^{\text {ref }} \text { ur : elastic unloading, } \\
& \mathrm{v}_{\mathrm{ur}} \quad \text { : elastic reloading. }
\end{aligned}
$$

As seen from Fig. 5, stress-strain curve tends to be non-linear for the primary loading. $\mathrm{E}_{50}$ represents the stiffness modulus that depends on confining stress at initial loading. Thus, $\mathrm{E}_{50}$ is utilized on behalf of initial modulus $E_{i}$ for smaller strain parameters. $\mathrm{E}_{50}$ can be determined as,

$E_{50}=E_{50}^{r e f}\left(\frac{c^{\prime} \cos \phi^{\prime}-\sigma_{3}^{\prime} \sin \phi^{\prime}}{c^{\prime} \cos \phi^{\prime}+p^{r e f} \sin \phi^{\prime}}\right)^{m}$

Where,

$E_{50}^{\text {ref }}$ : Stiffness occuring with respect to the reference stress ' $p$ ref,

$\sigma_{3}^{\prime}$ : Effective confining pressure determined from triaxial test

In finite element software, PLAXIS [2], reference stress value is taken as a $100 \mathrm{kN} / \mathrm{m}^{2}$. Effective confining pressure determines the actual stiffness and it takes negative value in compression.

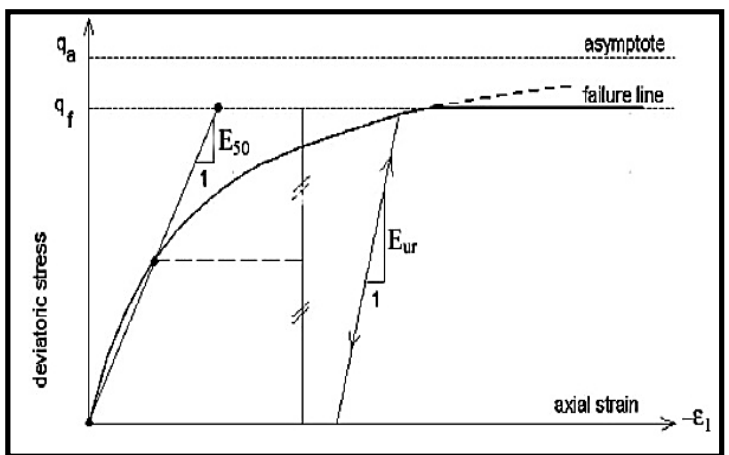

(*) Negative values mean compression in the graph

Fig. 5. Hyperbolic stress-strain graph in hardening soil model [10]

It can be seen from Fig. 5, there are loading condition, unloading condition and reloading condition. Stiffness modulus for these loading conditions is determined as,

$E_{u r}=E_{u r}^{r e f}\left(\frac{c^{\prime} \cos \phi^{\prime}-\sigma_{3}^{\prime} \sin \phi^{\prime}}{c^{\prime} \cos \phi^{\prime}+p^{r e f} \sin \phi^{\prime}}\right)^{m}$

Where,

$E_{u r}^{r e f}$ : Stiffness occuring with respect to the reference stress ' $p$ 're', for unloading case and reloading case.

Finite element software, PLAXIS [2] takes $E_{u r}^{r e f}$ as three times of $E_{50}^{r e f}$.

Definition of $\mathrm{E}_{\text {oed }}{ }^{\text {ref }}$ from oedometer test results is demonstrated in Fig 6.

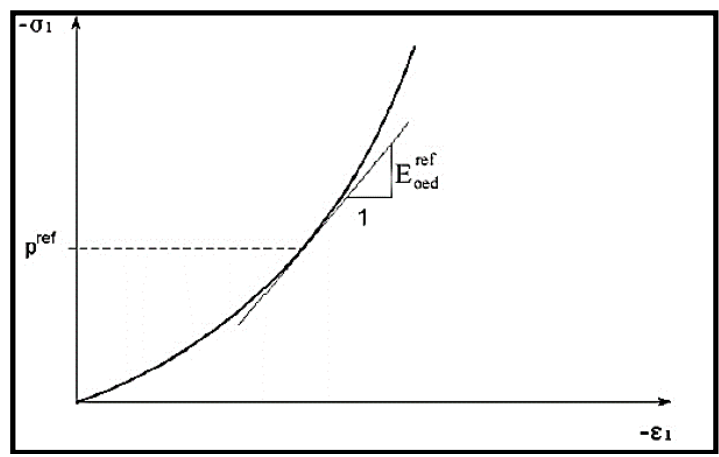

(*) Negative values mean compression in the graph

Fig. 6. Definition of Eoed ${ }^{\text {ref }}$ from oedometer test results [10]

Plastic shear strain under deviatoric loading is displayed by friction hardening and plastic 
volumetric strain under primary compression is modeled by cap hardening. Friction hardening differs from cap hardening. Friction hardening is utilized to obtain irreversible plastic strains, these strains occur as a result of primary deviatoric loading. Compression hardening is utilized to obtain irreversible plastic strains and these strains comprise as a result of primary compression under both isotropic loading and oedometer loading. The present model includes both of the hardening types that are explained above [11]. Model comprises of yield contours that is seen in 3D from the Fig. 7.

\subsubsection{Material model parameters}

Material Model Parameters used in the analysis are presented in Tables (2-4).

\subsubsection{Mesh model}

In PLAXIS [2] program, settlements are calculated at nodes. Finite element system is formed with 6node triangle mesh elements or 15-node triangle mesh elements. In this study, 15-node triangle element model is used to model Aydın Karacasu Dam.

The model comprises of 8125 nodes, 990 Soil Elements, 11,880 Global Stress Points. The model is shown in the Fig. 8.

\subsubsection{Analysis method}

Analysis of the dam is carried out by stage construction method, recalling that embankment is formed in layers. Stage construction affects stress dispersion and deformations occurred in vertical or horizontal direction [12]. Layer thickness affects the analysis results. Analyses conducted by smaller layer thicknesses, is more accurate. However, it takes too much computation time [5].

In this study, imaginary axes are defined at the maximum cross-section of the dam to show locations of instrumentation devices. Imaginary axes are shown in the Fig. 9. Hydraulic settlement devices are located in six different axes of the dam body. As seen in the Fig. 9, ZDÖ2 is located in axis $\mathrm{X}_{1}-\mathrm{X}_{1}, \mathrm{ZDÖ} 9$ is located in axis $\mathrm{X}_{2}-\mathrm{X}_{2}, \mathrm{ZDÖ} 10$ and ZDÖ22 are located in axis $\mathrm{X}_{3}-\mathrm{X}_{3}$, ZDÖ11, ZDÖ23 and ZDÖ29 are located in axis $X_{4}-X_{4}, Z D O ̈ 12$ and ZDÖ24 are located in axis $\mathrm{X}_{5}-\mathrm{X}_{5}$ and ZDÖ13 is located in axis $\mathrm{X}_{6}-\mathrm{X}_{6}$.

Table 2. Parameters used in hyperbolic models for sandgravel fill material of Aydın Karacasu Dam

\begin{tabular}{|c|c|c|c|c|c|}
\hline $\begin{array}{c}\text { Triaxial } \\
\text { Stiffness } \\
\text { E}_{50}{ }^{\text {ref }} \\
(\mathrm{kPa})\end{array}$ & $\begin{array}{c}\text { Triaxial } \\
\text { Unloading } \\
\text { Stiffness } \\
\text { Eur }_{\text {ref }} \\
(\mathrm{kPa})\end{array}$ & $\begin{array}{l}\text { Oedometer } \\
\text { Loading } \\
\text { Stiffness } \\
\text { Eoed }^{\text {ref }} \\
(\mathrm{kPa})\end{array}$ & $\begin{array}{c}\text { Unit } \\
\text { weight } \\
(\gamma) \\
\left(\mathrm{kN} / \mathrm{m}^{3}\right)\end{array}$ & $\begin{array}{c}c \\
\left(\mathrm{kN} / \mathrm{m}^{2}\right)\end{array}$ & $\phi$ \\
\hline 30,000 & 90,000 & 30,000 & 17.2 & 2 & $38^{\circ}$ \\
\hline
\end{tabular}

Table 3. Parameters used in hyperbolic models for bedrock material of Aydin Karacasu Dam

\begin{tabular}{cccc}
\hline $\begin{array}{c}\text { Elasticity } \\
\text { Modulus }\end{array}$ & Unit weight $\gamma$ & $c\left(\mathrm{kN} / \mathrm{m}^{2}\right)$ & $\phi$ \\
\hline $600,000 \mathrm{KPa}$ & $22 \mathrm{kN} / \mathrm{m}^{3}$ & 25 & $40^{\circ}$ \\
\hline
\end{tabular}

Table 4. Parameters used in hyperbolic models for concrete slab of Aydin Karacasu Dam

\begin{tabular}{cccc}
\hline $\mathrm{EA}(\mathrm{kN} / \mathrm{m})$ & $\mathrm{EI}\left(\mathrm{kNm}^{2} / \mathrm{m}\right)$ & $d(m)$ & $v$ \\
\hline $8,550,000$ & 64,125 & 0.30 & 0.20 \\
\hline
\end{tabular}
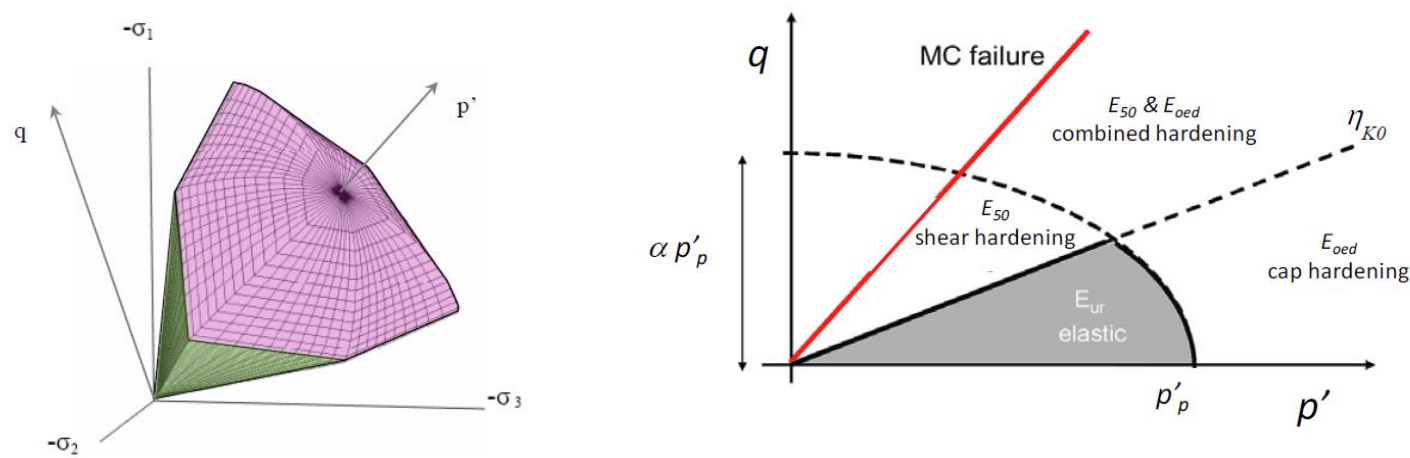

Fig. 7. Total yield contours of hardening soil model under principal stresses for cohesionless soil [11] 


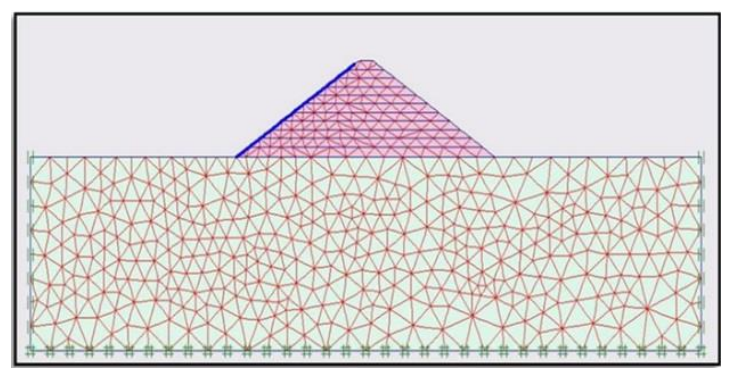

Fig. 8. Connectivity in mesh analysis of Aydın Karacasu Dam [2]

As stated above, two-dimensional deformation analyses are carried out for the end of construction (EOC) and the reservoir impoundment (RI) stages. for the maximum cross-section, $\mathrm{Km} \mathrm{0+300.00} \mathrm{m} \mathrm{of}$ the dam. Sand-gravel fill material deforms under only its own weight for end of construction condition. However, water load causes additional deformation in the embankment for reservoir impoundment condition (RI). Settlement calculations are made in stages starting from the foundation level and advancing upwards layer by layer. For each layer settlements are calculated at specific points where hydraulic settlement devices are located. At the end of each layer, recorded settlements are reset to zero and intermediate steps are deleted. Then, calculated settlements are superposed to find the total settlements at specific points for EOC and RI conditions.

In the analyses, it is assumed that, the rock foundation of the Aydın Karacasu Dam is infinitely rigid. It is also assumed that there is a perfect bond between concrete slab and sand-gravel fill. It is decided to utilize $5 \mathrm{~m}$ layers in the analyses.

\section{Results of analyses}

\subsection{End of construction analyses (EOC)}

Embankment is formed by sand-gravel material prior to impounding. Results of analyses for end of construction condition are presented in Table 5.

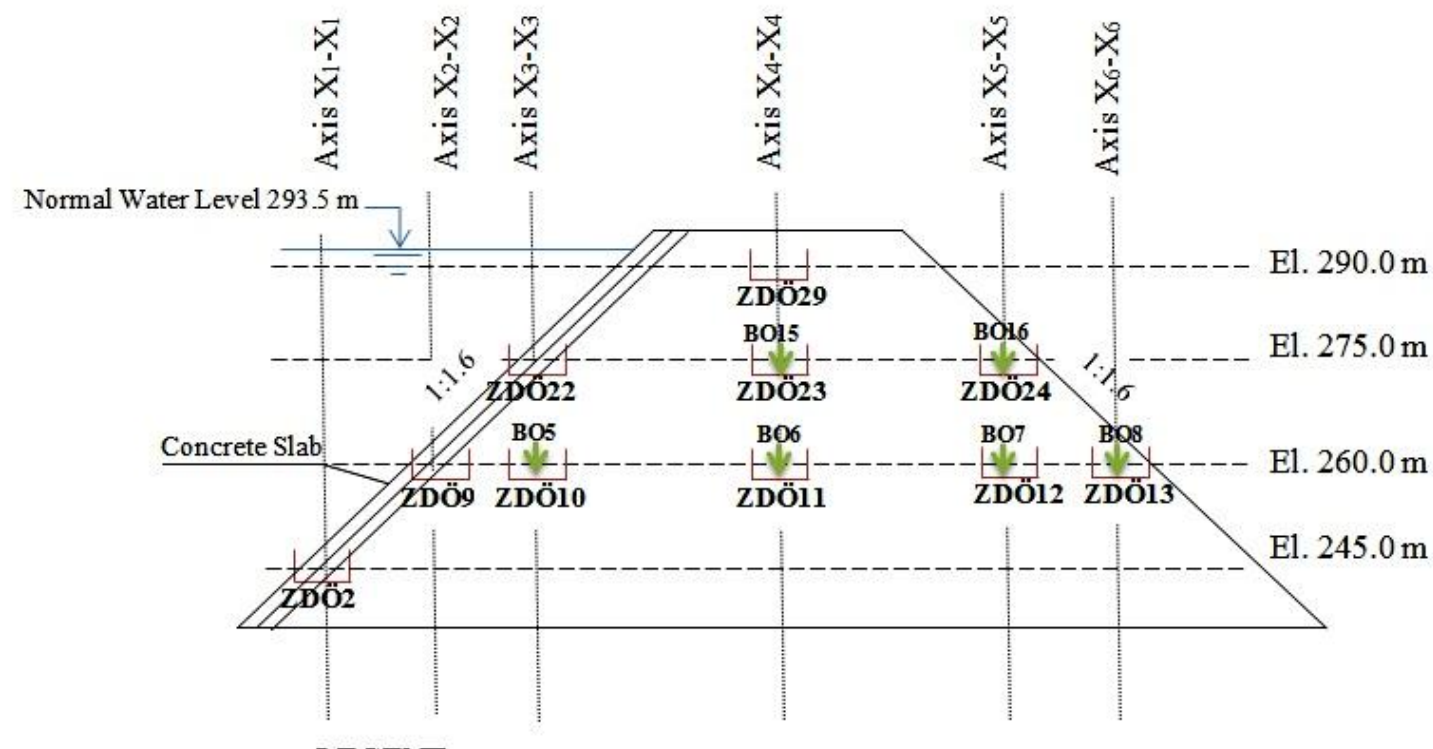

LEGEND:

\section{: Hydraulic Settlement Device}

\section{: Pressure Gauge}

Fig. 9. Location of imaginary axes and instrumentation devices at maximum cross-section (Km: $0+300.00 \mathrm{~m})$ of Aydın Karacasu Dam 
Table 5. Results of analyses of Aydın Karacasu dam at max. cross-section (Km 0+300.00 m) for EOC

\begin{tabular}{|c|c|c|c|c|c|c|c|c|c|}
\hline Axes & $\mathrm{X}_{2}-\mathrm{X}_{2}$ & & & & $\mathrm{X}_{4}-\mathrm{X}_{4}$ & & & & $\mathrm{X}_{6}-\mathrm{X}_{6}$ \\
\hline Instrument & ZDÖ9 & ZDÖ10 & ZDÖ22 & ZDÖ11 & ZDÖ23 & ZDÖ29 & ZDÖ12 & ZDÖ24 & ZDÖ13 \\
\hline Elevation (m) & 260.00 & 260.00 & 275.00 & 260.00 & 275.00 & 290.00 & 260.00 & 275.00 & 260.00 \\
\hline $\begin{array}{l}\text { Vertical Settlement } \\
\text { Observed by DSİ } \\
(\mathrm{cm})\end{array}$ & -36.0 & -22.0 & -28.0 & -23.0 & -37.5 & -32.0 & -27.0 & -32.0 & -28.0 \\
\hline $\begin{array}{l}\text { Calculated Vertical } \\
\text { Settlement by } \\
\text { PLAXIS [2] (cm) }\end{array}$ & -15.0 & -27.9 & -23.0 & -32.5 & -35.5 & -21.6 & -26.2 & -18.8 & -16.5 \\
\hline $\begin{array}{l}\text { Difference between } \\
\text { Observed Settlement } \\
\text { and PLAXIS [2] } \\
\text { Results (cm) }\end{array}$ & -21.0 & 5.9 & -5.0 & 9.5 & -2.0 & -10.4 & -0.8 & -13.2 & -11.5 \\
\hline $\begin{array}{l}\% \text { Difference between } \\
\text { Observed Settlement } \\
\text { and PLAXIS [2] } \\
\text { Results }\end{array}$ & 58.4 & 26.6 & 17.7 & 41.4 & 5.3 & 32.4 & 2.9 & 41.1 & 41.1 \\
\hline
\end{tabular}

(*) In the Table “-” settlement value shows compression.

\subsection{Reservoir impoundment (RI)}

A large part of post-construction deformations occurs during reservoir impoundment. Settlements increase by the rising water level. Large settlements may cause cracks in the concrete slab and leakage problems may emerge as a result of these cracks in the concrete slab.

In Aydin Karacasu Dam, reservoir impounding started in 07.09.2012. Water level reached El. $293.50 \mathrm{~m}$ in a short time and then ultimately reached El. $298.17 \mathrm{~m}$. After end of construction of the dam body, majority of the deformations occur during first impounding so, first impounding is a critical condition that should be analyzed [5]. Thus, El. $293.50 \mathrm{~m}$ is considered as a critical condition to be considered in calculations.

Concrete slab is presumed as uncracked and impervious in the finite element analyses and water load is assumed as acting in a perpendicular direction to the concrete slab and calculated as a triangle-shaped distributed load as shown in the Fig. 10 below.

The maximum water load (at El $240.00 \mathrm{~m}$ ) is $524.835 \mathrm{kN} / \mathrm{m}^{2}$. It decreases with increasing elevations. Reservoir impounding analyses are conducted at five imaginary axes defined above.
Results of the analyses for reservoir impounding condition are shown in Table 6.

It can be observed from Table 6 Maximum observed settlement recorded as $45,50 \mathrm{~cm}$ on axis $\mathrm{X}_{4}-\mathrm{X}_{4}$ for RI, which is measured by device ZDÖ23 located at $62.5 \%$ of the height of the dam above the bottom. Maximum vertical settlement is calculated as $39.30 \mathrm{~cm}$ at El. $271 \mathrm{~m}$ at $55.00 \%$ of the dam height.

Tables 7, 8 show the impact of water loading on vertical settlements, recorded by DSI and calculated by finite element analyses. EOC settlements are not included in these values, which are indicated in the following tables to show the reservoir impounding effect on the deformation behavior of the dam body. Therefore, vertical settlement values observed at the end of construction are subtracted from the ones observed when reservoir impounding reaches El $293.50 \mathrm{~m}$.

\section{Conclusions}

Today, concrete faced sand gravel fill dams (CFSGD) are very popular all over the world, since, these constructions are important structures; their deformation behavior should be estimated realistically for both construction and reservoir filling stages. 


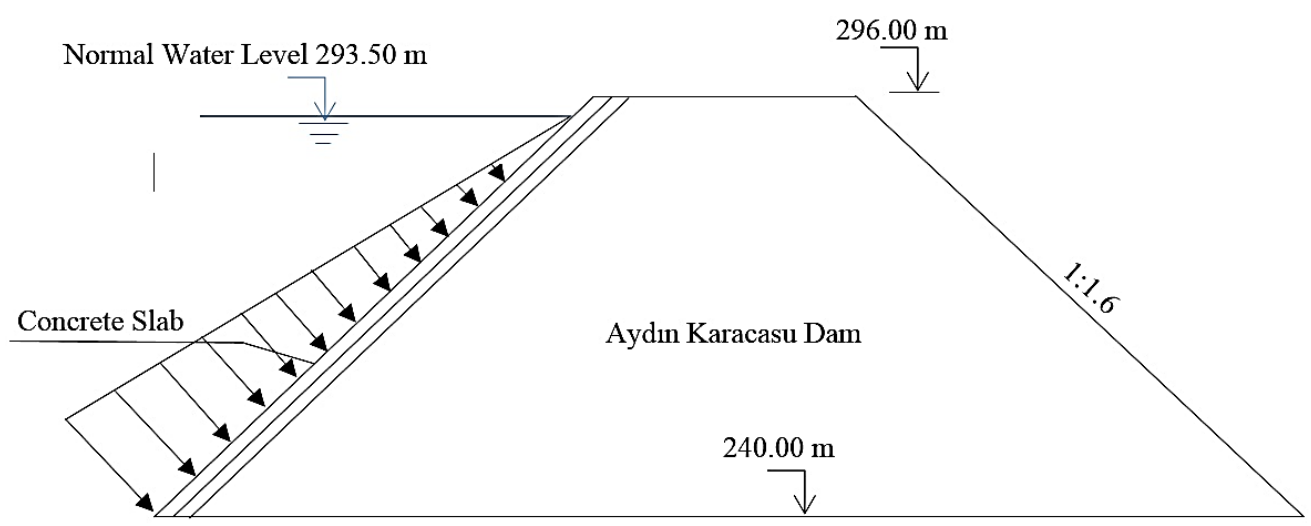

Fig. 10. Water load acting on the concrete membrane of the dam

Table 6. Results of analyses of Aydın Karacasu Dam at max. Cross-section (Km 0+300.00 m) for RI Condition

\begin{tabular}{|c|c|c|c|c|c|c|c|c|c|}
\hline Axis & $\mathrm{X}_{2}-\mathrm{X}_{2}$ & $\mathrm{X}_{3}-\mathrm{X}_{3}$ & & $\mathrm{X}_{4}-\mathrm{X}_{4}$ & & & $\mathrm{X}_{5}-\mathrm{X}_{5}$ & & $\mathrm{X}_{6}-\mathrm{X}_{6}$ \\
\hline Instrument & ZDÖ9 & ZDÖ10 & ZDÖ22 & ZDÖ11 & ZDÖ23 & ZDÖ29 & ZDÖ12 & ZDÖ24 & ZDÖ13 \\
\hline Elevation (m) & 260.00 & 260.00 & 275.00 & 260.00 & 275.00 & 290.00 & 260.00 & 275.00 & 260.00 \\
\hline $\begin{array}{l}\text { Settlement Observed by } \\
\text { DSİ }(\mathrm{cm})\end{array}$ & -44.0 & -32.0 & -41.0 & -40.0 & -45.5 & -44.0 & -40.0 & -42.0 & -41.0 \\
\hline $\begin{array}{l}\text { Calculated Settlement } \\
\text { by PLAXIS [2] }(\mathrm{cm})\end{array}$ & -23.5 & -31.6 & -28.7 & -35.1 & -38.8 & -25.3 & -28.1 & -21.4 & -17.6 \\
\hline $\begin{array}{l}\text { Difference between } \\
\text { Settlement Observed by } \\
\text { DSİ and Settlement } \\
\text { Calculated by PLAXIS } \\
{[2](\mathrm{cm})}\end{array}$ & -20.5 & -0.4 & -12.3 & -4.9 & -6.7 & -18.7 & -11.9 & -20.6 & -23.4 \\
\hline $\begin{array}{l}\% \text { Difference between } \\
\text { Observed Settlement } \\
\text { and Calculated } \\
\text { Settlement by PLAXIS } \\
\text { [2] }\end{array}$ & 46.5 & 1.1 & 30.0 & 12.3 & 14.7 & 42.5 & 29.9 & 49.0 & 57.0 \\
\hline
\end{tabular}

(*) In the Table "-" settlement values shows compression.

Table 7. Effect of reservoir impounding on vertical settlements as measured by DSI

\begin{tabular}{|c|c|c|c|c|c|c|c|c|c|}
\hline Axis & $\mathrm{X}_{2}-\mathrm{X}_{2}$ & & $X_{3}$ & & $\mathrm{X}_{4}-\mathrm{X}_{4}$ & & & & $\mathrm{X}_{6}-\mathrm{X}_{6}$ \\
\hline Instrument & ZDÖ9 & ZDÖ10 & ZDÖ22 & ZDÖ11 & ZDÖ23 & ZDÖ29 & ZDÖ12 & ZDÖ24 & ZDÖ13 \\
\hline Elevation (m) & 260.00 & 260.00 & 275.00 & 260.00 & 275.00 & 290.00 & 260.00 & 275.00 & 260.00 \\
\hline $\begin{array}{l}\text { Settlement } \\
\text { Observed by DSİ } \\
\text { for EOC }(\mathrm{cm})\end{array}$ & -36.0 & -22.0 & -28.0 & -23.0 & -37.5 & -32.0 & -27.0 & -32.0 & -28.0 \\
\hline $\begin{array}{l}\text { Settlement } \\
\text { Observed by DSİ } \\
\text { for RI }(\mathrm{cm})\end{array}$ & -44.0 & -32.0 & -41.0 & -40.0 & -45.5 & -44.0 & -40.0 & -42.0 & -41.0 \\
\hline $\begin{array}{l}\text { Effect of Reservoir } \\
\text { İmpounding }(\mathrm{cm})\end{array}$ & -8.0 & -10.0 & -13.0 & -17.0 & -8.0 & -12.0 & -13.0 & -10.0 & -13.0 \\
\hline
\end{tabular}


Table 8. Effect of reservoir impounding on vertical settlements calculated by PLAXIS [2]

\begin{tabular}{lccccccccc}
\hline Axes & $\mathrm{X}_{2}-\mathrm{X}_{2}$ & \multicolumn{2}{c}{$\mathrm{X}_{3}-\mathrm{X}_{3}$} & \multicolumn{3}{c}{$\mathrm{X}_{4}-\mathrm{X}_{4}$} & \multicolumn{2}{c}{$\mathrm{X}_{5}-\mathrm{X}_{5}$} & $\mathrm{X}_{6}-\mathrm{X}_{6}$ \\
\hline Instrument & ZDÖ9 & ZDÖ10 & ZDÖ22 & ZDÖ11 & ZDÖ23 & ZDÖ29 & ZDÖ12 & ZDÖ24 & ZDÖ13 \\
\hline $\begin{array}{l}\text { Elevation (m) } \\
\text { Settlements }\end{array}$ & 260.00 & 260.00 & 275.00 & 260.00 & 275.00 & 290.00 & 260.00 & 275.00 & 260.00 \\
$\begin{array}{l}\text { Calculated by } \\
\text { PLAXIS [2] for }\end{array}$ & -15.0 & -27.9 & -23.0 & -32.5 & -35.5 & -21.6 & -26.2 & -18.8 & -16.5 \\
$\begin{array}{l}\text { EOC (cm) } \\
\text { Settlements }\end{array}$ & & & & & & & & & \\
$\begin{array}{l}\text { Calculated by } \\
\text { PLAXIS [2] for }\end{array}$ & -23.5 & -31.6 & -28.7 & -35.1 & -38.8 & -25.3 & -28.1 & -21.4 & -17.6 \\
$\begin{array}{l}\text { RI (cm) } \\
\begin{array}{l}\text { Effect of Reservoir } \\
\text { Impounding (cm) }\end{array}\end{array}$ & -8.5 & -3.7 & -5.7 & -2.6 & -3.3 & -3.7 & -1.9 & -2.6 & -1.1 \\
\hline
\end{tabular}

In this study; settlement analyses of Aydin Karacasu Dam, the first concrete faced sand-gravel dam of Turkey, are conducted by using two dimensional PLAXIS finite element program [2]. Results of analyses, are compared with observed ones recorded by DSİ. Following conclusions may be drawn from this study:

- Difference between the calculated and observed ones decreases with increasing elevations, nevertheless, the observed and calculated settlement are in general agreement. Poor quality of compaction or irregular readings taken from instrumentation devices during end of construction and reservoir impoundment may be the cause of those differences between observed and calculated vertical displacements.

- For the end of construction condition, majority of the calculated values obtained from both finite element program results are compatible with observed settlement values. Maximum vertical settlement is found as $36,20 \mathrm{~cm}$ which corresponds to about $55 \%$ of the total dam height from the foundation base by PLAXIS [2]. These results show that compressibility of the fill material decreases with increasing elevations.

- In the reservoir full condition, analyses results indicate that most of the calculated settlements are somewhat smaller than the observed ones; except settlements calculated in axis $\mathrm{X}_{4}-\mathrm{X}_{4}$. In axis $\mathrm{X}_{4}-\mathrm{X}_{4}$, maximum calculated vertical settlement is found as $39.30 \mathrm{~cm}$ which corresponds to about $55 \%$ of the total dam height above the base. Results of analyses $\mathrm{X}_{3^{-}}$ $\mathrm{X}_{3}$ and $\mathrm{X}_{4}-\mathrm{X}_{4}$ are compatible with observed values. Results of RI analyses show that reservoir impounding has significant effect on regions closer to upstream membrane.

A few number of observed values which were out of practical range indicating malfunctioning of the devices were eliminated. It may be concluded that soil deformations, under loading and unloading conditions, during end of construction and reservoir impoundment periods can be estimated reasonable accuracy by two-dimensional FEM analysis. It is suggested that, for future studies, 3D finite element analyses may be utilized to compare the observed and calculated settlements in order to derive more reliable conclusions.

\section{References}

[1] Haselsteiner R, Ersoy B. Seepage control of concrete faced dams with respect to surface slab cracking. 6th International Conference on Dam Engineering, 2011, Lisbon, Portugal.

[2] Vermeer PA, Brinkgreve RBJ (1998) PLAXIS: Finite element code for soil and rock analyses (Version 8.2), Balkema, Rotterdam.

[3] Hydraulic State Works (2011), DSİ Report on Aydın Karacasu Dam.

[4] Singh B, Varshney RS. Engineering for embankment dams. AA. Balkema Publishers, Brookfield, 1995. 
[5] Özkuzukıran RS. (2005). "Settlement behavior of concrete faced rockfill dams, a case study. MSc Thesis. Middle East Technical University, 2005.

[6] Duncan JM, Chang CY (1970) Nonlinear analysis of stress and strains in soils. Journal of the Soil Mechanics and Foundations Division, ASCE 96(5): 1629-1653.

[7] Janbu N (1963) Soil compressibility as determined by oedometer and triaxial tests. Proceedings of European Conference on Soil Mechanics and Foundation Engineering (ECSMFE), 1963, Wiesbaden, Germany.

[8] Kondner RL (1963) Hyperbolic stress-strain response: cohesive soils. Journal of the Soil Mechanics and Foundations Division, ASCE 89(1): 115-143.

[9] Duncan JM, Byrne P, Wong KS, Babry P (1980) Strength, stress-strain and bulk modulus parameters for finite element analyses of stresses and movements in soil masses. Report No: UCB/GT/80-01, University of California, Berkeley.

[10] Schanz T, Vermeer PA, Bonnier PG. The hardening soil model: formulation and verification. Beyond 2000 in Computational Geotechnics-10 Years of Plaxis, 1999, Balkema, Rotterdam.

[11] Ti KS, Huat BK, Noorzaei J, Jaafar MS, Sew GS (2009) A review of basic soil constitutive models for geotechnical application. Electronic Journal of Geotechnical Engineering, EJGE 14: 1-18.

[12] Clough RW, Woodward RJ (1967) Analysis of embankment stresses and deformations. Journal of the Soil Mechanics and Foundations Division, ASCE 93(4). 